\title{
KONTRIBUSI DAN TIPOLOGI PEMIKIRAN HADIS MUHAMMAD DAILAMY DALAM BIDANG HADIS DI JAWA TENGAH
}

\author{
${ }^{1}$ Diyan Faturahman, ${ }^{2}$ Nur Kholis \\ 1,2Universitas Ahmad Dahlan Yogyakarta \\ E-Mail: diyanfaturahman@gmail.com,nur.kholis@ilha.uad.ac.id
}

\begin{abstract}
Research on hadith figures has not been done much, even though their contribution in preserving the source of the second Islamic law is very much. Muhammad Dailamy is one of the most influential hadith figures in Central Java. In this research, it will be explained about the contribution and typology of thought of his hadith. This research is a type of qualitative research. In collecting data, researchers used the interview method with a semi-structured interview technique. The data obtained is processed and analyzed using descriptive-analytical methods. In addition, tShe data sources used also include Dailamy's own intellectual work and other literature relating to research objects, both from books, journals, and internet media. Furthermore, to find out the typology of thought of his hadith, researchers used a theory built by M. Syuhudi Ismail about the typology of thought and understanding of textual-contextual hadith. The results showed that Muhammad Dailamy's contributions in the field of hadith were among others preachers who had considerable influence in the community, especially in the Purbalingga, Purwokerto, Banyumas, Banjarnegara and surrounding areas. Since 1990 he has been active as a presenter of the Mutiara Pagi program at RRI Purwokerto station. In addition, he is also productive in making of books in the form of study series. Then in understanding the traditions of Muhammad Dailamy it can be classified as a typology of contextual flow. This can be marked by his statement that the understanding of Muslim hadith number 106 about isbal must know the existing context
\end{abstract}

Keywords: hadith, Muhammad Dailamy, typology of thought; Central Java

Abstrak: Penelitian tentang tokoh hadis belum banyak dilakukan, padahal kontribusi merekadalammenjagadan melestarikansumberhukum Islam yangkeduainisangatbanyak. Muhammad Dailamy merupakan salah satu tokoh hadis yang cukup berpengaruh di Jawa Tengah. Dalam penelitian ini akan dijelaskan tentang kontribusi dan tipologi pemikiran hadisnya. Penelitian ini merupakan jenis penelitian kualitatif. Dalam mengumpulkan data, peneliti menggunakan metode wawancara dengan teknik wawancara semistruktur. Data yang diperoleh kemudian diolah dan dianalisis menggunakan metode deskriptifanalitis. Sumber data yang digunakan juga meliputi karya intelektual Dailamy sendiri dan juga literatur lain yang berhubungan dengan objek penelitian, baik dari buku, jurnal, maupun media internet. Selanjutnya, untuk mengetahui tipologi pemikiran hadisnya, peneliti menggunakan teori yang dibangun oleh M. Syuhudi Ismail tentang tipologi pemikiran dan pemahaman hadis tekstual-kontekstual. Hasil penelitian menunjukkan bahwa kontribusi Muhammad Dailamy dalam bidang hadis antara lain sebagai mubalig yang memiliki pengaruh cukup luas di lingkungan masyarakat khususnya daerah Purbalingga, Purwokerto, Banyumas, Banjarnegara dan sekitarnya. Sejak tahun 1990 aktif menjadi pemateri acara Mutiara Pagi di stasiun RRI Purwokerto. Selain itu, ia juga produktif dalam membuat karya tulis berupa buku dalam bentuk seri kajian. Kemudian dalam memahami hadis Muhammad Dailamy dapat digolongkan kepada tipologi aliran 
kontekstual. Hal tersebut dapat ditandai dengan pernyataannya bahwa pemahaman hadis Muslim nomor 106 tentang isbal harus mengetahui konteks yang ada.

\section{Kata kunci: hadis, Muhammad Dailamy, tipologi pemikiran; Jawa Tengah}

\section{PENDAHULUAN}

Meskipun kajian hadis di Indonesia sudah dimulai sejak abad ke-17 masehi ${ }^{1}$, namun masih jarang ditemukan penelitian yang menyangkut tentang tokoh hadis, khususnya di Jawa Tengah. Padahal Indonesia sendiri merupakan negara dengan penduduk muslim mayoritas di seluruh dunia ${ }^{2}$, begitupun di Jawa Tengah yang juga memiliki penduduk mayoritas muslim ${ }^{3}$ denganjumlah pondok pesantren sebanyak 5850 unit per tahun $2015^{4}$. Hal tersebut memungkinkan jumlah tokoh hadis yang ada sebenarnya cukup banyak. Namun karena kurangnya penelitian yang mengambil tema studi tokoh, sehingga kontribusi mereka dalam berbagai aspek bidang maupun pemikirannya tidak dapat diketahui dengan mudah maupun diidentifikasi secara lebih luas.

Penelitian tentang tokoh hadis di Indonesia sebenarnya sudah cukup banyak yang mengkaji, antara lain ialah A. Hasan ${ }^{5}$,

1 Afriadi Putra, "Pemikiran Hadis KH. Hasyim Asy'ari dan Kontribusinya terhadap Kajian Hadis di Indonesia" dalam Wawasan: Jurnal Ilmiah Agama dan Sosial Budaya 1, 1 (Januari 2016): 46-55

2 Hackett, C., Grim, B. J., Stonawski, M., Skirbekk, V., Potančoková, M., \& Abel, G. J. (2012). The Global Religious Landscape A Report on the Size and Distribution of the World's Major Religious Groups as of 2010. (December), 1--81. https://doi. org/10.13140/2.1.4573.8884

3 BPS, Sensus Penduduk 2010 (SP 2010): update tanggal 14 Agustus 2018, dalam https://jateng.bps.go.id/ statictable/2015/02/09/791/penduduk-menurut-agamajenis-kelamin-dan-kabupaten-kota-hasil-sensuspenduduk-tahun-2010.html (Diakses: 11 Januari 2020)

4 Kanwil. Departemen Agama Provinsi Jawa Tengah. Banyaknya Pondok Pesantren, Kyai Ustadz dan Santri Menurut Kabupaten/Kota di Jawa Tengah, 2014-2015 dalam https:// jateng.bps.go. id/dynamictable/2019/01/23/61/ banyaknya-pondok-pesantren-kyai-ustadzdan-santri-menurut-kabupaten-kota-di-jawatengah-2014-2015.html (Diakses: 11 Januari 2020)

5 M. Fatih, "Hadis dalam Perspektif Ahmad Hassan"
Buya Mawardi ${ }^{6}$, Hasbi Ash-Shiddieqy ${ }^{7}$, KH. Hasyim Asy'ari ${ }^{8}$, Mahmud Yunus ${ }^{9}$, Ramli Abdul Wahid ${ }^{10}$, Syaikh Mahłuż al-Tirmasi ${ }^{11}$, Syaikh Yasin al-Fadani ${ }^{12}$,

dalam Mutawâtir: Jurnal Keilmuan Tafsir Hadis Volume 3, Nomor 2, Desember 2013, hlm. 325

Jannatul Husna bin Ali Nuar, "Kaedah Pengkaryaan Hadis Arba'in oleh Syeikh Fādān̄̄ dan Buya Mawardi”, 2016.

7 Aan Supian, "Kontribusi Pemikiran Hasbi Ashiddieqy dalam Kajian Ilmu Hadis", dalam Mutawâtir: Jurnal Keilmuan Tafsir Hadis Volume 4, Nomor 2, Desember 2014, hlm. 271

8 Afriadi Putra, "Pemikiran KH M. Hasyim Asy'ari dan Kontribusinya terhadap Kajian Hadis di Indonesia" dalam Wawasan: Jurnal Ilmiah Agama dan Sosial Budaya 1, 1 (Januari 2016): hlm. 46-55

9 Febriyeni, "Studi Pemikiran Tokoh Hadis Sumatera Barat : Prof. H. Mahmud Yunus dan H. Mawardi Muhammad", Tesis: Konsentrasi Ilmu Hadis Program Studi Pengkajian Islam Pascasarjana IAIN Imam Bonjol Padang dalam http://repository.uinib.ac.id/63/, diakses 21 Desember 2017

10 Hemawati, "Kontribusi dan Pemikiran Ramli Abdul Wahid Sebagai Tokoh dalam Bidang Hadis di Sumatera Utara (2005-2010)", dalam Wahana Inovasi Volume 3 No.2 Juli-Des 2014, hlm. 287

11 Hanief Monady, "Syeikh Mahfûż al Tirmasî (Biografi dan Kontribusinya dalam Studi Hadis)", 2015, makalah dalam https://www.academia. edu/20310409/Syeikh_Mahfudz_Thermas Biografi dan Kontribusi di Bidang Hadis ? auto=download, diakses pada 21 Desember 2017.

12 Mohd. Khafidz bin Soroni dan Mohd. Norzi bin Nasir, "Ketokohan Syeikh Muhammad Yasin Al Fadani dan Sumbangannya dalam Disiplin Periwayatan Sanad", sebuah makalah dalam https://archive.org/_stream/ KetokohanSyeikhMuhammadYasinAlFadani/ Ketokohan\%20Syeikh\%20Muhammad\%20 Yasin\%20al-Fadani_djvu.txt, diakses 21 Desember 2017 ; Jannatul Husna bin Ali Nuar dan Fauzi Deraman, "Syeikh Yasin Padang dan Hadith Arba'in: Sebuah Ulasan dan Takhrij" dalam Sunnah Nabi, Realiti dan Cabaran Semasa (Kuala Lumpur: Akademi Pengajian Islam Universiti Malaya), 2011, h. 161. 
Syamsul Anwar's, Syuhudi Ismail ${ }^{14}$. Namun penelitian tentang tokoh hadis yang berasal dari Jawa Tengah secara lebih khusus masih sangat sulit ditemukan. Hal itulah yang juga mendasari dilakukannya penelitian ini.

\section{HASIL DAN PEMBAHASAN}

\section{Latar Historis Muhammad Dailamy}

a. Latar Belakang Keluarga dan Kepribadian Muhammad Dailamy

Muhammad Dailamy merupakan anak ke tujuh dari sepuluh bersaudara. Ia lahir di Banjarnegara, Jawa Tengah pada hari Sabtu, 12 Rabbi'ul Tsani 1365 Hijriyah, bertepatan dengan tanggal 16 Maret 1946 Miladiyah dari pasangan Ahmad Mukri dan Urip. Kedua orangtuanya merupakan orang yang dihormati di tengah masyarakat. Hal tersebut karena mereka memiliki budi pekerti dan sifat yang luhur serta sifat dermawan yang membuat masyarakat semakin hormat. Ayahnya merupakan seorang penganut tarekat Naqsabandiyah, selain itu juga termasuk orang yang keras dan disiplin dalam mendidik anak-anaknya. Sementara ibunya adalah orang yang sangat memperhatikan pendidikan bagi anak-anaknya ${ }^{15}$ juga penganut tarekat Syattariyah. Dengan demikian, anakanaknya termasuk Dailamy dididik dan dibesarkan dalam lingkungan keluarga yang religius. Meskipun orangtuanya penganut tarekat, namun mereka tidak menutup diri terhadap dakwah Islam yang

13 Fadlilah Wakhikmatu Fidin, "Pemikiran Hadis Syamsul Anwar: Studi Interkoneksi Ilmu Hadis dengan Astronomiâ" dalam skripsi (Yogyakarta:Universitas Ahmad Dahlan), 2017.

14 Fithriady Ilyas dan Ishak bin $\mathrm{Hj}$. Suliaman, "Muhammad Syuhudi Ismail (1943-1995); Tokoh Hadis Prolifik, Ensklopedik dan Ijtihad", dalam Jurnal Ilmiah ISLAM FUTURA Vol. 17. No. 1, Agustus 2017, hlm. 1

15 Karena dorongan ibunyalah, Dailamy menjadi orang yang berhasil di bidang akademik, khususnya dalam ilmu hadis. Ibunya hanya merestui Dailamy melanjutkan ke sekolah agama, lain tidak. Sumber: wawancara dengan Muhammad Dailamy di rumahnya, Purwokerto pada Sabtu, 7 April 2018 pukul 09.30 WIB. diberikan oleh siapapun. Termasuk dalam hal ini adalah mubalig Muhammadiyah. Sejak tahun 1958 rumah mereka sering menjadi tempat tinggal mubalig tersebut, dari sinilah Dailamy mulai banyak belajar tentang wawasan dan pendidikan agama Islam, termasuk di dalamnya hadishadis Nabi. Ia menjadi paham tentang perbuatan takhayul, bidah dan khurafat yang berkembang di masyarakat ${ }^{16}$.

Dailamy dikenal sebagai anak yang cerdas dan disayang oleh para gurunya. Ia memiliki sifat disiplin, rajin, gemar membaca buku dan tidak pernah absen untuk membaca Alquran setiap kali usai salat fardu ${ }^{17}$. Ketika kuliah di Yogyakarta, ia aktif dalam organisasi kemahasiswaan Himpunan Mahasiswa Islam (HMI). Ketika sedang tidak ada tugas di luar kota, ia selalu menyempatkan diri untuk menulis. Kemampuan Dailamy dalam hal ilmu agama Islam pada umumnya maupun dalam bidang hadis secara khusus sudah mulai tumbuh sejak muda. Dailamy sudah terbiasa memberikan ceramah di kampungnya sejak usia 15 tahunan. Ia dipercaya memberikan ceramah di beberapa masjid dan musala di tempat tinggalnya, bahkan hingga berceramah ke kampung tetangga. Selain aktif mengajar agama di lingkungan masyarakat, ia juga menjadi dosen di berbagai perguruan tinggi.

\section{b. Pendidikan Muhammad Dailamy}

Ia mengawali pendidikan formalnya di Sekolah Rakyat Negeri Bojanegara, kemudian pada penghujung tahun 1959 ia melanjutkan ke Sekolah Pendidikan Guru AgamaPertama(SPGAP)Muhammadiyah Banjarnegara dan lulus pada tahun 1962. Pada tahun 1962 masuklah Dailamy

16 Wawancara dengan Muhammad Dailamy di rumahnya, Purwokerto pada Sabtu, 7 April 2018 pukul 09.30 WIB.

17 Wawancara dengan Ibnu Athailah, kakak ipar M. Dailamy di Imogiri, Yogyakarta pada hari Jum'at, 15 Desember 2017 pukul 14:00 WIB. Ketika kuliah di IAIN Sunan Kalijaga, ia tinggal di rumah Ibnu Athailah daerah Bumijo, sebelah utara stasiun Tugu, yang selanjutnya berjodoh dengan adik kandung Ibnu. 
ke SPIAIN Purworejo ${ }^{18}$. Setelah lulus dari SPIAIN Purworejo, ia melanjutkan studinya di fakultas syariah jurusan hadis IAIN Sunan Kalijaga Yogyakarta. Setelah mendapat gelar sarjana muda, ia memilih jurusan jurusan hadis. Salah satu alasan Dailamy mengambil jurusan hadis yaitu, apabila seseorang memahami hadis, kemungkinan besar juga memahami Alquran, karena hadis itu sendiri merupakan penjelas Alquran. Selama kuliah di IAIN Sunan Kalijaga Yogyakarta $^{19}$, ia termasuk golongan mahasiswa ikatan dinas. Ia juga menempuh Studi Purnasarjana ${ }^{20}$ dan lulus pada tahun 1980 dengan peringkat yang memuaskan. Kemudian pada tahun 2005, ia berhasil memperoleh gelar doktor dari UIN Syarif Hidayatullah Jakarta dalam disiplin ilmu kajian Islam ${ }^{21}$. Selanjutnya pada hari Rabu, 18 Februari 2009 Daelamy dikukuhkan sebagai guru besar dalam bidang ilmu hadis yang pertama di IAIN Purwokerto ${ }^{22}$

Beberapa gurunya antara lain; Asjmuni Abdurrahman, Badri Yatim, Harun Nasution, HM. Rasjidi, M.

18 Pada saat itu, SPIAIN Purworejo baru membuka pendaftaran untuk angkatan pertama. Dailamy memperoleh informasi tersebut setelah mencari informasi sekolah agama sampai ke Wonosobo. Sebelum berangkat, ibunya berpesan, "aja leren, sakdurunge inyong sing leren disitan (jangan berhenti bersekolah sebelum saya meninggal dunia, red),". Sebuah motivasi yang besar yang diberikan seorang ibu. Dengan Bismilah, ia sanggup membiayai anakanaknya sekolah, bahkan semangat itulah yang kelak akan mendorong Dailamy untuk berani melanjutkan S3, ia berprinsip "in syaa' Allah saya tidak akan melarat karena kuliah",

19 Sekarang UIN Sunan Kalijaga

20 Sekarang Pascasarjana

21 MuhammadDailamy, Hadis SemenjakDisabdakan Sampai Dibukukan (Purwokerto:STAIN Purwokerto Press, 2010), hlm. 395. Ia melanjutkan studi S3 melalui program pemerintah yaitu S3 by riset. Setelah sebelumnya mengajukan proposal Desertasi, ia diterima sebagai mahasiswa S3 di UIN Syarifhidayatullah Jakarta.

22 Lihat https://wongpwt.wordpress. com/2009/03/18/guru-besar-pertama-stainpurwokerto/. Diakses pada hari Kamis, 11 Januari 2018.
Quraish Shihab, Mukhtar Yahya, Mukti Ali, Said Agil Husein al-Munawwar, TM. Hasbi Ashiddieqy, Zakiyah Darajat, dll ${ }^{23}$. Said Agil Husein al-Munawwar yang pernah menjadi Menteri Agama Republik Indonesia pernah memberikan pernyataan, "kalau namanya hadis, disiniada orang yang lebih paham tentang hadis, orang itu adalah Ust. Dailamy," 24 Ia mengajar di STM Muhammadiyah Yogyakarta ketika tengah merampungkan kuliah di IAIN Sunan Kalijaga. Selanjutnya pindah ke Universitas Islam Indonesia Purwokerto, ${ }^{25}$ lalu mengajar di IAIN Purwokerto. Selain itu menjadi dosen juga di Pascasarjana Universitas Muhammadiyah Purwokerto (UMP). Bahkan ia juga diamanati sebagai ketua BPH STIKES Muhammadiyah Gombong dan pernah menjadi ketua pembangunan gedung rektorat STIKES Muhammadiyah Gombong tersebut ${ }^{26}$. Ia juga menjadi bagian dari salah satu pendiri Institut Agama Islam Muhammadiyah (IAIM) Purwokerto ${ }^{27}$. Adapun di Kendal, ia menjabat sebagai Ketua STIT Muhammadiyah Kendal ${ }^{28}$.

23 Wawancara dengan Muhammad Dailamy di rumahnya, Purwokerto pada Sabtu, 7 April 2018 pukul 09.30 WIB.

24 Wawancara dengan Muhammad Dailamy

25 Tahun 1962, UII melebarkan sayap dan membuka cabang di beberapa daerah, diantaranya di Purwokerto. Sumber diperoleh dari https://www. uii.ac.id/sejarah-kami/ diakses Kamis, 11 Januari 2018.

26 Wawancara dengan Ibu Sri Rejeki. Lihat juga Supriyanto/CN39/SMNetwork /suaramerdeka.com dalam http://www.beritakebumen. info/2013/11/din-syamsuddin-resmikan-gedungrektorat.html. Diakses Jumat, 13 April 2018 pukul 21.46 WIB.

27 IAIM selanjutnya melebur pada IKIP Muhammadiyah Purwokerto menjadi fakultas tarbiyah. Dalam perkembangannya IKIP Muhammadiyah Purwokerto ini menjadi Universitas Muhammadiyah Purwokerto (UMP), sedangkan Fakultas Tarbiyah menjadi Fakultas Agama Islam

28 M. Dailamy SP., Validitas Hadis "Man Shâma Ramadhâna Wa Atba'ahu Sittân Min Syawâlin Kâna ka Shiyâmid Dahri" dalam JURNAL DIDAKTIKA ISLAMIKA Volume 6, Nomor 2Agustus 2015 
Kontribusi Muhammad Dailamy dalam Bidang Hadis

\section{a. Karya Intelektual Muhammad Dailamy}

Muhammad Dailamy mulai aktif menulis sejak tahun 1980, tepatnya ketika ia sedang menyelesaikan Program Pascasarjana. Beberapa artikelnya dimuat dalam majalah Suara Muhammadiyah dan jurnal akademik. Sebagian besar dari karyanya itu ditulis dalam bentuk buku berseri atau buku seri kajian. Sampai saat penelitian ini dilakukan, buku seri kajian tersebut sudah mencapai seri kajian keempat belas. Dari sekian karya tulisnya yang terdeteksi, penulis dapat mengelompokkan menjadi beberapa kategori sebagai berikut:

1) Dalam bidang Akidah - Tauhid antara lain;

b) 25 Hadis Prediksi Nabi Atas Umatnya, Dilengkapi Doa dari AlQur'ān Karim dan Sunnah Sahihah, (2011);
c) 3 Prinsip Hidup Pengantar Masuk Surga;
d) Kembali kepada al-Quran dan al-Sunnah ('Ala Manhaj Muhammadiyah), 2013;
e) Sepuluh Jalan Menuju Muslim yang Sebenar-benarnya, (2015);
f) Syaitan, Penggoda Profesional dan Berlisensi, Pengacak dan Pencemar Shadaqah Anak Adam (2017).

2) Dalam bidang Alquran - Tafsir antara lain;
a) Empat Persoalan Perempuan dalam Agama (Perspektif Qur'an Hadis), 2016
b) Ramadhan Mubarak (Perspektif Al- Qur'an dan Hadis), 2012 ;
c) Allah-Manusia-Bumi dan Bencana Alam Perspektif Qur'an Hadis, (2017).

3) Dalam bidang Sejarah - Budaya antara lain;

a) Dari Menghidupkan Ramadhan Sampai Dengan Budaya Silaturahim di Indonesia, Salah Kaprah, Bener Tidak Lumrah Mencari Akar Kaitan, (2009).

4) Dalam bidang Fikih - Hukum antara lain;
a) Melaksanakan Ajaran Agama, Mengapa Berbeda Cara, Menelusuri Asal Muasal, Mengurai Benang Kusut, (2011).
b) Belajar Sholat Bersama Rasulullah SAW.
c) Santri Bertanya Ustadz Dailamy Menjawab, (2016).
d) Tuntunan Praktis Menunaikan Ibadah Haji (2015).

5) Dalam bidang Hadis - Ilmu Hadis antara lain;
a) Hadis-hadis Kitab Bulughul Maram, Kajian Atas Ketepatan Penulisan dan Kesahihan Hadis (2006).
b) Hadis Semenjak Disabdakan Sampai Dibukukan, (2010).
c) Ilmu Hadis, (2015).
d) Validitas Hadis "Man Shâma Ramadhâna Wa Atba'ahu Sittân Min Syawâlin Kâna ka Shiyâmid Dahri" terbit dalam salah satu jurnal ilmiah.
5) Dalam bidang Pendidikan - Akhlak antara lain Konsep Akhlak dalam Pandangan Al-Ghazali, tulisan tersebut terbit dalam salah satu jurnal ilmiah.

Dengan melihat kuantitas serta judul karya tersebut, dapat diketahui keahliannya dalam bidang Alquran dan Hadis, serta latar belakang penulisanya, antara lain: a) adanya kepekaan terhadap kondisi sosial yang terjadi di sekitar; b) antusias dari murid atau jamaahnya yang membutuhkan bimbingan keagamaan sehari-hari; c) tuntutan akademik, mengingat posisinya selain sebagai guru di tengah masyarakat, juga sebagai dosen di perguruan tinggi. 


\section{b. Metode Syarah Hadis}

Menurut M. Alfatih Suryadilaga, metodologi syarah hadis dari era klasik hingga kontemporer dibagi ke dalam beberapa hal yang meliputi metode syarah hadis, pendekatan syarah hadis dan pola syarah hadis. Metode syarah hadis dibagi menjadi tiga, yakni; (a) Metode tahlili, (b) Metode ijmali, (c) Metode muqaranah. Selain itu, ada juga yang menambahkan, yakni dengan metode maudu'i. Pendekatan syarah hadis dibagi menjadi tiga, yakni; (a) Memahami hadis dengan pendekatan historis, (b) Pemahaman hadis berbasis pendekatan sosiologi dan (c) Memahami hadis dengan pendekatan antropologi. Adapun, pola syarah hadis dibagi menjadi empat, antara lain; (a) Memahami hadis Nabi dengan Al-Qur'an, (b) Memahami hadis dengan hadis, (c) Memahami hadis Nabi dengan pendekatan bahasa dan (d) Memahami hadis Nabi dengan ijtihad. Berdasarkan teori Alfatih Suryadilaga tersebut, maka dapat disebut bahwa metode dan pola yang digunakan Dailamy dalam mengajarkan atau mensyarah hadis yaitu berdasarkan metode tahlili $^{29}$ dan memahami hadis dengan ijitihad. Penggunaan metode tahlili yang dilakukan oleh Dailamy tersebut disampaikan secara langsung kepada peneliti ketika melakukan wawancara. Hal tersebut dikuatkan dengan corak kitab Fatḥul Bârĩ Bi Syarhi Șahĩh al-Bukhârĩ yang juga menggunakan metode tahlili dalam penjelasannya. Sementaara, kitab tersebut berikut pengarangnya merupakan rujukan utama Dailamy dalam mempelajari hadis Nabi. ${ }^{30}$

Metode tahlili merupakan metode yang digunakan dalam mengurai, menganalisis dan menjelaskan maknamakna yang terkandung dalam hadis Rasulullah SAW dengan memaparkan

29 Wawancara dengan Muhamamd Dailamy, di rumahnya Purwokerto, Sabtu, 7 April 2018.

30 Muthoifin, Mengungkap Isi Pendidikan Islam Perspektif Al-Qur'an Surat Al-Ashr Ayat 1-3, Proseding the 7th University Research Colloqium 2018STIKES PKU Muhammadiyah Surakarta aspek-aspek yang terkandung di dalamnya sesuai dengan keahlian dan kecenderungan pensyarah ${ }^{31}$. Pensyarah memulai penjelasannya dengan mengutarakan makna kalimat demi kalimat, hadis demi hadis secara berurutan. Uraian tersebut menyangkut berbagai aspek yang dikandung hadis seperti kosakata, konotasi kalimatnya, asbāb al-wurūd (jika ditemukan), kaitannya dengan hadis lain dan pendapat-pendapat yang beredardi sekitar pemahaman hadis tersebut, baik yang berasal dari sahabat, para tabiin maupun para ulama hadis ${ }^{32}, 33$

Dalam buku M. Alfatih Suryadilaga tersebut disampaikan beberapa kitab hadis yang menggunakan metode tahlili dalam mensyarah hadis, salah satunya yaitu kitab fathul bârĩ bi syarḥi Șahĩh alBukhârĩ. Kitab tersebut merupakan rujukan Dailamy dalam mengkaji hadis Nabi SAW. Sedangkan penulisnya, yakni Ibnu Hajar al-Asqalani merupakan ulama yang banyak mempengaruhi pemikiran hadis Dailamy. ${ }^{34}$ Menurutnya, Ibnu Hajar selalu memberikan solusi alternatif dan petunjuk dalam membahas suatu persoalan, begitupun ketika memberikan dalil dalam suatu hukum, misalnya menyampaikan bahwa hadis tersebut dhaif dan sebagainya. ${ }^{35}$ Dalam mencari rujukan, ketika Dailamy sudah tidak mampu lagi mengeluarkan ijtihadnya, ia membuka kitab fathul bârĩ. Apabila,

31 M. Al-Fatih Suryadilaga, Metodologi Syarah Hadis Era Klasik Hingga Kontemporer Potret Konstruksi Metodologi Syarah Hadis (Yogyakarta: SUKA-Press UIN Sunan Kalijaga, 2012), hlm. 18

32 Penjelasan ini disampaikan oleh Nizar Ali dalam ringkasan disertasinya dengan judul Kontribusi Imam Nawawi dalam Penulisan Syarah Hadis yang kemudian dikutip oleh M. Al-Fatih Suryadilaga dalam bukunya Metodologi Syarah Hadis Era Klasik Hingga Kontemporer, hlm. 19.

33 Muthoifin, Proseding the 3rd University Research Colloquium 2016, Kontekstualisasi Makna Zakat: Studi Kritis Kosep Sabilillah Menurut Masdar Farid Mas'udi, 2016.

34 Wawancara dengan Muhammad Dailamy, di rumahnya Purwokerto, Sabtu, 7 April 2018.

35 Wawancara dengan Muhammad Dailamy, di rumahnya Purwokerto, Sabtu, 7 April 2018. 
dalam kitab tersebut tidak ditemukan qarinah untuk membantu menyelesaikan permasalahan yang ada, Dailamy kemudian membuka kitab Talkhis al-Habir yang juga karya Ibnu Hajar al-Aśqalani. Begitupun ketika mentarjih hadis, ia juga biasa menggunakan kitab Talkhis al-Habir tersebut. Apabila mentakhrij hadis, Dailamy melihat karangan Arent Jan Wensinck dalam kitabnya $M u^{\prime} j a m$ Mufahros Li Alfadzi Hadits al Nabawiyah.

\section{c. Pola Syarah Hadis}

Pola yang dilakukan dalam menyampaikan pengajian atau kajian rutin, ia jelaskan materi tersebut sesuai buku yang ditulisnya dalam bentuk seri kajian. Pola syarah hadis yang dilakukan oleh Dailamy yakni dengan menggunakan pola memahami hadis Nabi dengan ijtihad..$^{36}$ Ijtihad dalam syarah hadis yaitu suatu cara berfikir sungguh-sungguh para ulama dengan segenap kemampuannya untuk menginterpretasikan suatu hadis agar diperoleh suatu pemahaman baru yang mungkin biasanya memunculkan suatu hukum-hukum baru. ${ }^{37}$ Ruang lingkupnya meliputi kata, frasa, kalimat, asbāb al-wurūd, munāsabah, dan sebagainya yang dapat digunakan dalam bentuk yang ma'sur. sedangkan, ijtihad sendiri hanya dilakukan pada jenis hukum yang sifatnya żanni. Tujuannya yaitu agar diperoleh suatu pemahaman baru yang mungkin biasanya memunculkan suatu hukumhukum baru, mengaplikasikan maksud dari suatu hadis dan untuk memenuhi keperluan umat manusia akan pegangan hidup dalam beribadah kepada Allah SWT di suatu tempat tertentu atau pada suatu waktu tertentu. Langkah dalam menggunakan ijtihad dalam pemahaman hadis itu sendiri adalah sebagai berikut;;

\footnotetext{
36 Informasi ini diperoleh dari muridnya, Jefri Lisaldi di Masjid Ahmad Dahlan, Universitas Muhammadiyah Purwokerto, Senin 9 April 2018 pukul 15.30 WIB.

37 M. Al-Fatih Suryadilaga, Metodologi Syarah Hadis, hlm. 140

$38 \quad$ Ibid, hlm. 141
}

1) Melakukan uji validitas hadis yang akan disyarahi. Di dalamnya meliputi pengaplikasian kritik sanad dan matan hadis. Dalam hal ini, hadis tidak bertentangan dengan petunjuk al-Qur'ān, tidak bertentangan dengan hadis yang lebih kuat, maupun akal sehat, indra dan fakta sejarah serta susunan pernyataannya menunjukkan ciri-ciri kenabian. ${ }^{39}$

2) Jika hadis tersebut sahih, namun pada konteks saat hadis disyarahi belum bisa diaplikasikan, maka langkah selanjutnya adalah dengan menggunakan ijtihad.

Adapun di antara bentuk ijtihad yang dikemukakan oleh Dailamy antara lain;

a) Setelah mandi wajib tidak perlu berwudhu lagi, kecuali jika mengalami keadaan yang menyebabkan batalnya wudhu.

b) Pada saat menunaikan ibadah haji, tepatnya pada hari tarwiyah atau tanggal 8 Dzulhijjah diutamakan pergi ke Mina.

c) Salat Jum'at diwajibkan kepada seluruh umat muslim, baik laki-laki maupun perempuan. Hal ini karena dalam QS. AlJumu'ah ayat 9 berlaku untuk umum, baik laki-laki maupun perempuan. Sementara, hadis yang menerangkan tentang dalil pengecualian salat jumat dinyatakan lemah kualitasnya, sehingga tidak bisa dijadikan hujah. Adapun, terkait kaifiyat salatjumat bagi perempuan, tidak dijelaskan oleh Dailamy apakah menggunakan khutbah atau tidak, jelasnya bagi perempuan juga dinamakan salat Jum'at.

39 Kriteria ini diambil dari Salahuddin al-Adhabi dalam bukunya Manhaj Naqd al-Matn, yang dikutip oleh M. Al-Fatih Suryadilaga, Metodologi Syarah Hadis, hlm. 141 
d) Hukum berjabat tangan setelah salam dalam salat ialah ghairu masyru'.

e) Nabitidak pernah mencontohkan membaca Alquran di kuburan dan juga berziarah kubur pada saat hari raya Idul Fitri maupun Idul Adha.

f) Talkin dilakukan hanya kepada orang yang hendak meninggal dunia, tidak dibenarkan menalkinkan orang yang sudah meninggal dunia ${ }^{40}$.

\section{d. Kontekstualitas Pemikiran Hadis Muhammad Dailamy}

Melihat beberapa karya intelektual yang dibuat Dailamy, rata-rata judul tersebut diakhiri dengan kalimat perspektif Alquran dan hadis. Hal tersebut menunjukan adanya motivasi dari pengarang itu sendiri. Sehingga, memungkinkan adanya corak pemikiran atau lebih khusus lagi terkait dengan tipologi pemikiran hadisnya. Dalam membahas suatu persoalan, ia tidak lepas daripada pendekatan hadis. Sehingga dalam melihat permasalahan amal ibadah, Dailamy tidak pernah membedakan antara amal perbuatan yang wajib, sunah maupun yang lainnya. Akan tetapi, yang dijadikan pegangan baginya adalah "apakah perbuatan tersebut dilakukan oleh Rasulullah atau tidak". Dan hal itu perlu dilakukan penelusuran sumber hukum. Ketika merujuk pada hadis Nabi SAW, maka yang dijadikan dasar hukum adalah hadis yang sahih. ${ }^{41}$

Hadis dikatakan sahih jika memenuhi kriteria hadis sahih baik dari sisi sanad maupun matannya ${ }^{42}$. Meskipun

$40 \quad$ Wawancara dengan Muhammad Dailamy pada Sabtu, 7 April 2018

41 Wawancara dengan Muhammad Dailamy pada Sabtu, 7 April 2018. Menurutnya, dalam mengambil sumber hukum berdasarkan hadis, kualitas hadis tersebut harus sahih atau minimal hasan. Hadis dhaif tidak boleh dijadikan sebagai hujjah. (Iskandariyah: Markaz al-Huda li al-Dirâsât),

hadis tersebut terdapat dalam kitab rahihain, namun ketika matannya tidak memenuhi kriteria, maka Dailamy tidak mengambilnya sebagai hujah. Misalnya hadis tentang binatang yang haram karena berkuku tajam dan bertaring.

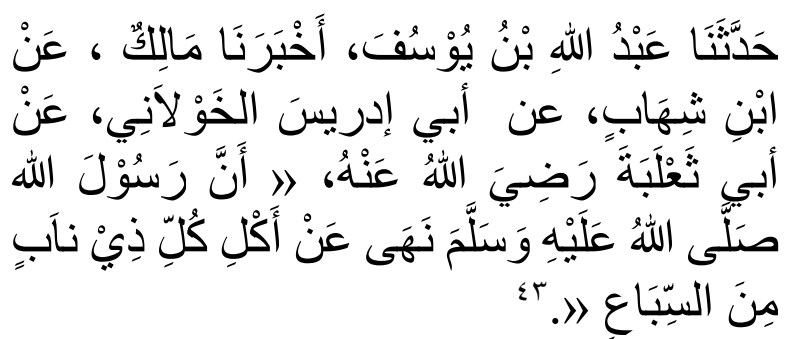

... Dari Abî @a'labah ra. "Bahwasanya Rasulullah saw. melarang memakan makanan setiap hewan buas yang bertaring," (HR. Al Bukhārī No. 5530)

Ketidaksahihan hadis tersebut disebabkan bertentangan dengan QS. Al-An'ām: 145. Meski demikian, bukan berarti Dailamy menghalalkan binatang berkuku tajam dan bertaring seperti anjing dan sebagainya ${ }^{44}$. Ia memiliki argumen selanjutnya, bahwa keharaman daging anjing disebabkan bukan merujuk pada hadis riwayat Muslim di atas, melainkan berdasarkan QS. Al-Mā'idah: 88 dan QS. Al-Baqarah: 168. Ayat tersebut merupakan perintah untuk memakan makanan yang halalan rayiban (halal lagi baik). Menurutnya, daging anjing tidak rayyib, sehingga dengan dasar ini Dailamy tetap mengharamkannya.

Dalam memahami hadis Nabi SAW, Dailamy termasuk orang yang memahaminya secara kontekstual. Memahami hadis secara kontekstual menurutnya tetap harus diiringi dengan berbagai pertimbangan. Dengan demikian, ia tidak pernah berfatwa bahwa

1995., hlm. 51 ;.Muhammad Dailamy, Ilmu Hadis (Purwokerto: 2015), hlm. 152

43 Abû 'Abdillâh Muhammad bin Ismâ'̂̂l al-Bukhârî, Sahîh al-Bukhârî (Beirut: Dâr al-Ma'rifah, 2014), hlm. 1409

44 Wawancara dengan Muhamamd Dailamy, di rumahnya Purwokerto, Sabtu, 7 April 2018. 
hadis riwayat Muslim no. 106 diterima secara tekstual. Disebutkan bahwa pada hari Kiamat Allah tidak akan mengajak bicara, tidak memandang dan tidak akan mensucikan serta menyediakan baginya siksaan yang pedih kepada al-musbil ${ }^{45}$.

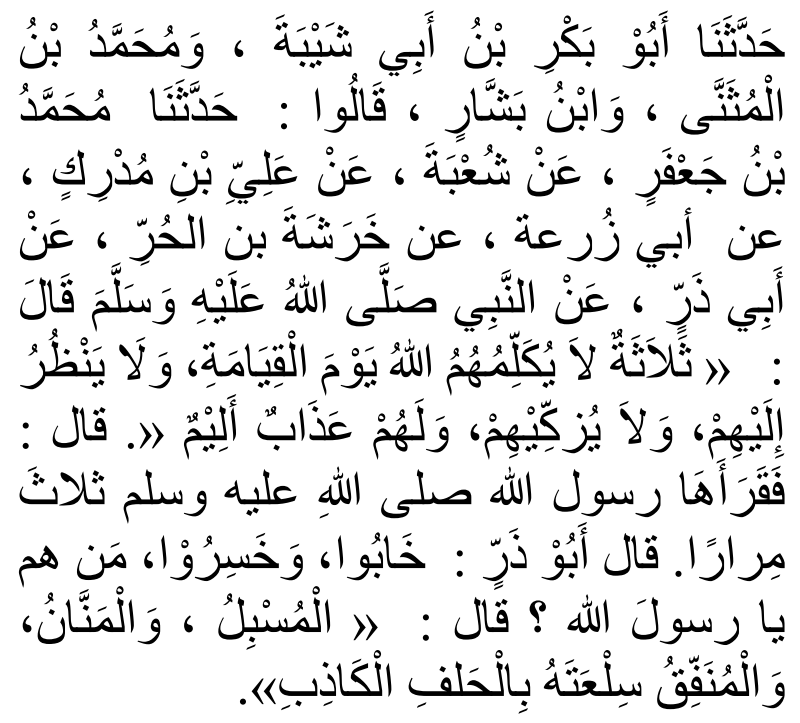

"Ada tiga jenis manusia yang tidak akan diajak biacar oleh Allah pada hari Kiamat, tidak dipandang, dan tidak akan disucikan oleh Allah. Untuk mereka bertiga siksaan yang pedih. Itulah laki-laki yang isbal, orang yang mengungkit-ungkit sedekah dan orang yang melariskan barang dagangannya dengan sumpah palsu". (HR. Muslim No. 106) ${ }^{46}$

Untuk hal tersebut Dailamy berkomentar, "Keterangan tersebut tidak dapat diterima oleh akal sehat, bahwa hanya karena alasan memanjangkan sarung, celana atau sejenisnya mendapat ancaman yang keras di hari Kiamat, bahkan disediakan siksaan yang pedih" ${ }^{\prime \prime 7}$. Selain itu, ia juga menyebutkan riwayat lain yang berisi tentang illat atau penyebab musbil disiksa oleh Allah, yakni karena adanya kesombongan.

45 Seseorang yang memanjangkan baju, sarung, celana atau yang sejenisnya di bawah mata kaki. Hadis selengkapnya dapat dilihat riwayat Muslim No. 106.

46 Muslim bin al-Hajjâj al-Qusyairî al-Naisâbûrî, Sahîh Muslim (Kairo: Zâduka ilâ al-Ma'rifah, 2012), hlm. 44

47 Wawancara dengan Muhamamd Dailamy, di rumahnya Purwokerto, Sabtu, 7 April 2018.
Dalam hal ini, pendapatnya sama dengan majelis tarjih Muhammadiyah, bahwa yang dimaksud tidak dipandang oleh Allah yakni dikarenakan adanya kesombongan, baik pria maupun wanita. Hal itu menunjukkan orang yang memanjangkan pakaian sampai di bawah tumit atau menyentuh tanah, kalau tanpa disertai sifat sombong, maka tidak termasuk dalam ancaman itu. Hal tersebut dijelaskan oleh hadis lain riwayat al-Bukhārī, Abu Daud dan an-Nasai, bahwa Abu Bakar ra berkata kepada Nabi saw setelah mendengar hadis tersebut: "Sesungguhnya kain sarungku selalu melorot ke bawah kecuali saya menaikkannya", lalu Rasulullah saw menjawab kepada Abu Bakar ra: "Sesungguhnya engkau bukan termasuk yang melakukanya dengan sombong $48 "$ ".

Contoh di atas cukup menjadi dasar mengenai tipologi pemikiran hadis Muhammad Dailamy. Ia tidak melihat hadis secara tekstual, sehingga dalam memahami hadis riwayat Muslim no. 106 tidak serta merta diterima langsung, melainkan mencari hadis lain yang memiliki kesamaan materi atau matan yang disampaikan. Di mana, dalam riwayat yang lain disebutkan bahwa penyebab seseorang disiksa karena isbal ini dilandasi oleh adanya kesombongan. Adapun, ketika memahami hadis tentang tata cara ibadah mahdoh, yang menurut beberapa pendapat bahwa hadis tentang ibadah mahdoh tersebut harus dipahami secara tekstual, ia berpandangan bahwa; "bagaimana tidak bisa dipahami secara kontekstual, dalam arti membanding banyak hadis, misalnya bagaimana cara Nabi bertakbir, jika dipahami secara tekstual, maka hal ini akan menafikan hadis yang lain. Nabi Muhammad SAW kadang bertakbir bersama dengan mengangkat tangan, terkadang

48 Majelis Tarjih dan Tajdid Muhammadiyah, https:// tarjih.or.id/hukum-memakai-sarungcelana-dibawah-mata-kaki/. Diakses Selasa, 24 April 2018 pukul 21.07 WIB. 
bersamaan dan terkadang juga bertakbir dahulu baru mengangkat tangan. Padahal, semua hadis tersebut kualitasnya sahih, ${ }^{49}$

Dalam memahami hadis mmperhatikan gaya bahasa, kontes sosial, data historis, kultur, maupun kehidupan sosial Rasulullah saw. lainnya ${ }^{50}$, ia menyebutkan bahwa latar belakang hadis riwayat Muslim no. 106 tentang isbal adalah adanya illah yang menyebutkan kesombongan. Dengan demikian dapat kita simpulkan bahwa Dailamy membaca hadis secara kontekstual.

\section{e. Guru dan Dosen Ilmu Hadis}

Ia pernah tercatat sebagai guru AlQur'an dan Hadis diSTM Muhammadiyah Yogyakarta. Kemudian pada tahun 1971 menjadi dosen Ilmu Hadis ${ }^{51}$ di IAIN Purwokerto dan Universitas Muhammadiyah Purwokerto (UMP), baik program sarjana maupun pada program Pascasarjana UMP. Selain itu, ia juga menjadi ketua STIT Muhammadiyah Kendal. Sampai penelitian ini selesai ditulis, Dailamy masih aktif mengisi pengajian rutin di beberapa masjid di daeah Purwokerto, antara lain Masjid Mujahidin, Masjid Agung Baitussalam, dan Masjid At-Taqwa Ajibarang. Ia juga dikenal sebagai mubalig pertamina, karena memiliki jadwal rutin mengisi pengajian di perusahaan pertamina. Bahkan sejak tahun 1990 secara rutin setiap hari Senin pagi ${ }^{52}$, mengisi program

49 Wawancara dengan Muhammad Dailamy (menggunakan via WhatsApp, 20 Mei 2018), ia berargumen demikian ketika ditanyakan tentang bagaimana memahami hadis secara kontekstual tentang hadis-hadis yang berkaitan dengan ibadah mahdah.

50 Mukhlis Mukhtar, Pemahman Tekstual dan Kontekstual, hlm. 82 ; Ruslan Fariadi, Metode Praktis Penelitian Hadis, hlm. 71

51 Yang dimaksud dosen Ilmu Hadis di sini, tentunya meliputi cabang-cabang ilmu hadis seperti sejarah periwayaatan hadis, hadis tarbawi, pengantar ilmu hadis, dan sebagainya.

52 Pukul 05.00 sampai pukul 06.00 WIB. Metode yang dilakukan ialah, selama 30 menit hingga 40 menit Dailamy menjelaskan materi kajian. selanjutnya diberikan kesempatan tanya jawab yang dipandu oleh seorang moderator atau petugas di RRI Purwokerto. dialog interaktif dalam acara Mutiara Pagi di Radio Republik Indonesia (RRI) Purwokerto. Jangkauan radio ini meliputi daerah Purwokerto, Banyumas, Purbalingga, Banjarnegara, Cilacap, Tegal, Brebes, Kebumen, Wonosobo dan Pekalongan ${ }^{53}$. Acara Mutiara Pagi yang diisi oleh Dailamy ini juga pernah menjadi penelitian Hanifahridads (2017), mahasiswi Pascasarjana IAIN Purwokerto. Dalam kesimpulannya, ia menyebutkan bahwa pendengar acara Mutiara Pagi RRI Purwokerto dapat terbagi menjadi tiga posisi dalam memaknai pesan dakwah yang disiarkan melalui acara Mutiara Pagi, pertama pendengar menerima sepenuhnya pesan yang disampaikan oleh narasumber. Kedua ada pesan yang diterima, namun ada juga pesan yang ditolak. Adapun yang ketiga adalah khalayak menolak sepenuhnya pesan Islam yang disampikan oleh narasumber ${ }^{54}$.

Setelah dinyatakan pensiun dari IAIN Purwokerto, justru kegiatan dakwah Dailamy semakin luas. Bukan hanya menjadi pemateri kajian rutin di perusahaan pertamina, masjid AtTaqwa Ajibarang, Mujahidin, dan Baitussalam Purwokerto saja, ia juga sering memenuhi undangan pengajian dan tablig akbar yang diselenggarakan oleh pimpinan Muhammadiyah di tingkat ranting, cabang maupun daerah di wilayah Jawa Tengah. Selain itu juga menjadi pemateri dalam pelatihan-

Materi yang disampaikan merupakan apa yang sudah selesai ditulisnya dalam buku seri kajian. sampai penelitian ini dilaksanakan, materi kajian masih membahas tentang bencana alam, yang menurutnya sudah hampir dua tahun disampaikan belum juga selesai.

53 Informasi dari Bapak Wahyu, salah seorang pegawai RRI Purwokerto melalui pesan Whatsapp pada Rabu 11 April 2018.

54 Hanifahridads, Pesan Islam Melalui Radio: Analisis Resepsi Pendengar Mutiara Pagi RRI Purwokerto dalam Tesis (Program Studi Komunikasi dan Penyiaran Islam Pascasarjana: Institut Agama Islam Negeri Purwokerto), 2017. Hlm. 65 
pelatihan ataupun keynote speaker dalam agenda rapat kerja lembaga maupun pimpinan Muhammadiyah di beberapa daerah. Selain itu, dalam persyarikatan Muhammadiyah ia juga memiliki jabatan yang cukup penting. Kiprahnya dimulai dari ketua pimpinan ranting, berlanjut ke cabang, daerah dan berlanjut menjabat sebagai Wakil Ketua Pimpinan Wilayah Muhammadiyah (PWM) Jawa Tengah. Ia juga pernah menjadi anggota Majelis Tarjih, dan saat penelitian ini dilakukan mendapat amanah sebagai Pembina Lembaga Penanggulangan Bencana (LPB) dan Lembaga Pengembangan Cabang dan Ranting (LPCR) Pimpinan Wilayah Muhammadiyah (PWM) Jawa Tengah ${ }^{55}$.

\section{KESIMPULAN}

Berdasarkan pembahasan yang sudah diuraikan, maka dapat diambil kesimpulan antara lain sebagai berikut;

1. Muhammad Dailamy merupakan salah satu tokoh dalam bidang hadis yang memiliki pengaruh luas di masyarakat Karesidenan Banyumas dan sekitarnya. Kontribusinya dalam bidang hadis dapat dikategorikan ke dalam beberapa hal, di antaranya: a) dalam bidang karya tulis, Dailamy aktif membuat artikel tentang hadis serta buku-buku agama yang mana semua merujuk atau berdasarkan perspektif Alquran dan Hadis; b) berdasarkan informasi dari muridmuridnya, pola pengajaran hadis yang dilakukan oleh Dailamy menggunakan metode ijtihad. Adapun ketika mensyarah suatu hadis hadis atau menjelaskannya kepada orang lain, ia menggunakan metode tahlili; c) menjadi guru, mubalig, dan

55 Lihat https://pwmjateng.com/profil-pimpinan/, diakses pada Jumat, 13 April 2018. Pukul 22.55 WIB dosen dalam bidang hadis. Tercatat sejak tahun 1990 hingga sekarang, ia menjadi narasumber dalam program dialog interaktif 'Mutiara Pagi' di RRI Purwokerto yang mencakup daerah Purwokerto, Banyumas, Purbalingga, Banjarnegara, Cilacap, Tegal, Brebes, Kebumen, Wonosobo dan Pekalongan. Selain itu, masih aktif mengisi pengajian rutin di masjid At-Taqwa Ajibarang, Mujahidin dan Baitussalam Purwokerto serta berdakwah ke berbagai daerah. Ia merupakan salah satu pengurus Pimpinan Wilayah Muhammadiyah Jawa Tengah. Selain itu, ia juga tercatat sebagai guru besar pertama dalam bidang hadis di IAIN Purwokerto, dosen pascasarjana Universitas Muhammadiyah Purwokerto, ketua BPH STIKES Muhammadiyah Gombong dan ketua STIT Muhammadiyah Kendal.

2. Tipologipemikiranhadis Muhammad Dailamy dapat dikategorikan dalam kategori tipologi pemikiran hadis kontekstual. Hal ini dapat dilihat dalam banyak hadis yang dipahami, antara lain dalam memahami salah satu hadis Nabi Muhammad saw tentang isbal. Dalam memahami hadis tentang isbal tersebut, ia melihat konteks yang ada. Selain itu ia tidak pernah memahami hadis (mengamalkan ma'anil hadis) secara tekstual atau leterlek. Sebaliknya, selalu membandingkan dengan hadis yang lain, memperhatikan data historis, kultur, maupun kehidupan sosial Rasulullah. Dalam kaitannya dengan pemikiran hadisnya ini, ia banyak dipengaruhi oleh salah seorang ulama hadis termasyhur yaitu Imam Ibnu Hajar al-Aśqalan̄i. 


\section{DAFTAR PUSTAKA}

Al-Bukhârî, Abû 'Abdillâh Muhammad bin Ismâ'îl. (2014). Sahîh al-Bukhârî (Beirut: Dâr al-Ma'rifah), hlm. 1409

Al-Naisâbûrî, Muslim bin al-Hajjâj al-Qusyairî. (2012). Sahîh Muslim (Kairo: Zâduka ilâ al-Ma'rifah), hlm. 44

BPS, Sensus Penduduk 2010 (SP 2010): update tanggal 14 Agustus 2018, dalam https:// jateng.bps.go.id/statictable/2015/02/09/791/penduduk-menurut-agama-jeniskelamin-dan-kabupaten-kota-hasil-sensus-penduduk-tahun-2010.html (Diakses: 11 Januari 2020)

Dailamy, Muhammad. (2010). Hadis Semenjak Disabdakan Sampai Dibukukan (Purwokerto: STAIN Purwokerto Press), hlm. 395. . (2015). Ilmu Hadis (Purwokerto), hlm. 152

. (2015). Validitas Hadis "Man Shâma Ramadhâna Wa Atba'ahu Sittân Min Syawâlin Kâna ka Shiyâmid Dahri" dalam JURNAL DIDAKTIKA ISLAMIKA Volume 6, Nomor 2- (Agustus)

Fariadi, Ruslan. (2017). Metode Praktis Penelitian Hadis, Panduan bagi Pemula untuk Mentakhrij Hadis dan Membumikan Nilai Universal Matan Hadis. Yogyakarta: Mumtaz Publishing. hlm. 68

Fatih, M. (2013). "Hadis dalam Perspektif Ahmad Hassan" dalam Mutawâtir: Jurnal Keilmuan Tafsir Hadis Volume 3, Nomor 2. (Desember), hlm. 325

Febriyeni. (2015). “Studi Pemikiran Tokoh Hadis Sumatera Barat: Prof. H. Mahmud Yunus dan H. Mawardi Muhammad", Tesis: Konsentrasi Ilmu Hadis Program Studi Pengkajian Islam Pascasarjana IAIN Imam Bonjol Padang dalam http:// repository.uinib.ac.id/63/, diakses 21 Desember 2017

Fidin, Fadlilah Wakhikmatu. (2017). "Pemikiran Hadis Syamsul Anwar: Studi Interkoneksi Ilmu Hadis dengan Astronomiâ" dalam skripsi (Yogyakarta: Universitas Ahmad Dahlan).

Hackett, C., Grim, B. J., Stonawski, M., Skirbekk, V., Potančoková, M., \& Abel, G. J. (2012). The Global Religious Landscape A Report on the Size and Distribution of the World's Major Religious Groups as of 2010. (December), 1--81. https://doi. org/10.13140/2.1.4573.8884

Hanifahridads. (2017). Pesan Islam Melalui Radio: Analisis Resepsi Pendengar Mutiara Pagi RRI Purwokerto dalam Tesis (Program Studi Komunikasi dan Penyiaran Islam Pascasarjana: Institut Agama Islam Negeri Purwokerto). Hlm. 65

Hemawati. (2014). “Kontribusi dan Pemikiran Ramli Abdul Wahid Sebagai Tokoh dalam Bidang Hadis di Sumatera Utara (2005-2010)", dalam Wahana Inovasi Volume 3 No.2. (Juli-Des), hlm. 287

http://www.beritakebumen.info/2013/11/din-syamsuddin-resmikan-gedung-rektorat. html. Diakses Jumat, 13 April 2018 pukul 21.46 WIB.

https://pwmjateng.com/profil-pimpinan/, diakses pada Jumat, 13 April 2018. Pukul 22.55 WIB

https://tarjih.or.id/hukum-memakai-sarungcelana-di-bawah-mata-kaki/. Diakses 
Selasa, 24 April 2018 pukul 21.07 WIB.

https://wongpwt.wordpress.com/2009/03/18/guru-besar-pertama-stain-purwokerto/. Diakses pada hari Kamis, 11 Januari 2018.

https://www.uii.ac.id/sejarah-kami/ diakses Kamis, 11 Januari 2018.

Ilyas, Fithriady dan Ishak bin Hj. Suliaman. (2017). “Muhammad Syuhudi Ismail (1943-1995); Tokoh Hadis Prolifik, Ensklopedik dan Ijtihad", dalam Jurnal Ilmiah ISLAM FUTURA. Vol. 17. No. 1. (Agustus), hlm. 1

Kanwil. Departemen Agama Provinsi Jawa Tengah. Banyaknya Pondok Pesantren, Kyai Ustadz dan Santri Menurut Kabupaten/Kota di Jawa Tengah, 20142015 dalam https://jateng.bps.go.id/dynamictable/2019/01/ 23/61/banyaknyapondok-pesantren-kyai-ustadz-dan-santri-menurut-kabupaten-kota-di-jawatengah-2014-2015.html (Diakses: 11 Januari 2020)

Khafidz, Md. bin Soroni \& Md. Norzi bin Nasir. (2011). "Ketokohan Syeikh Muhammad Yasin Al Fadani dan Sumbangannya dalam Disiplin Periwayatan Sanad", sebuah makalah dalam https://archive.org/_stream/ Ke tokohanSyeikhMuhammadYasinAlFadani/Ketokohan\%20Syeikh\%20 Muhammad\%20Yasin\%20al-Fadani_djvu.txt, diakses 21 Desember 2017

Monady, Hanief. (2015). “Syeikh Mahfûż al Tirmasî (Biografi dan Kontribusinya dalam Studi Hadis)", makalah dalam https://www.academia.edu/20310409/ Syeikh_Mahfudz_ThermasBiografi_dan_Kontribusi_di_Bidang_ Hadis_?auto=download, diakses pada 21 Desember 2017.

Mukhtar, Mukhlis. (2011). Pemahaman Tekstual dan Kontekstual Pakar Hadis dan Pakar Fikih Seputar Sunnah Nabi, dalam Jurnal Hukum Diktum, Vol. 9 No. 1, Januari 2011, hlm. 82

Muthoifin, Mengungkap Isi Pendidikan Islam Perspektif Al-Qur'an Surat Al-Ashr Ayat 1-3, Proseding the 7th University Research Colloqium 2018 STIKES PKU Muhammadiyah Surakarta, 2018.

Muthoifin, Kontekstualisasi Makna Zakat: Studi Kritis Kosep Sabilillah Menurut Masdar Farid Mas'udi, Proseding the 3rd University Research Colloquium 2016.

Nuar, Jannatul Husna bin Ali dan Fauzi Deraman. (2011). "Syeikh Yasin Padang dan Hadith Arba'in: Sebuah Ulasan dan Takhrij" dalam Sunnah Nabi, Realiti dan Cabaran Semasa (Kuala Lumpur: Akademi Pengajian Islam Universiti Malaya), h. 161.

Nuar, Jannatul Husna bin Ali. (2016) “Kaedah Pengkaryaan Hadis Arba'in oleh Syeikh Fādānī dan Buya Mawardi".

Putra, Afriadi. (2016). “Pemikiran Hadis KH. Hasyim Asy'ari dan Kontribusinya terhadap Kajian Hadis di Indonesia" dalam Wawasan: Jurnal Ilmiah Agama dan Sosial Budaya 1, 1 (Januari): 46-55

Supian, Aan. (2014). "Kontribusi Pemikiran Hasbi Ashiddieqy dalam Kajian Ilmu Hadis", dalam Mutawâtir: Jurnal Keilmuan Tafsir Hadis Volume 4, Nomor 2. (Desember), hlm. 271

Suryadilaga, M. Al-Fatih. (2012). Metodologi Syarah Hadis Era Klasik Hingga Kontemporer Potret Konstruksi Metodologi Syarah Hadis (Yogyakarta: SUKA-Press UIN Sunan 
PROFETIKA, Jurnal Studi Islam, Vol.21, No. 1, Juni 2020: 31-44

Kalijaga), hlm. 18.

Thahân, Mahmûd. (1995). Taisîr Mustalah al-Hadîs, (Iskandariyah: Markaz al-Huda li al-Dirâsât), hlm. 51

\section{Wawancara:}

Wawancara dengan Ibnu Athailah, kakak ipar M. Dailamy di Imogiri, Yogyakarta pada hari Jum'at, 15 Desember 2017 pukul 14:00 WIB

Wawancara dengan Jefry Lisaldi, salah satu murid Dailamy di Universitas Muhammadiyah Purwokerto (UMP) pada Senin, 1 Januari 2018 di Purbalingga dan Masjid Ahmad Dahlan UMP

Wawancara dengan Muhammad Dailamy di rumahnya, Purwokerto pada Sabtu, 7 April 2018 pukul 09.30 WIB

Wawancara dengan Sri Rejeki, istri M. Dailamy, di rumahnya Purwokerto pada Senin, 1 Januari 2018 pukul 13.00 WIB

Wawancara dengan Wahyu, RRI Purwokerto melalui pesan Whatsapp pada Rabu, 11 April 2018

Wawancara selengkapnya dapat diakses pada hasil rekaman wawancara Studi Tokoh Hadis di Indonesia, Tipologi Pemikiran Hadis Muhammad Dailamy dan Kontribusinya dalam Bidang Hadis oleh Diyan Faturahman tahun 2018, dapat diakses di bit.ly/ wawancaraskripsi 